\title{
SPATIAL-TEMPORAL ANALYSIS OF LAND COVER AND USE CHANGES USING GIS TOOLS. CASE STUDY BĂNEASA NEIGHBORHOOD, BUCHAREST
}

\author{
SCĂUNAȘ Sofia ${ }^{a}$, PĂUNESCU C. ${ }^{\text {b }}$, MERCIU G.-L. ${ }^{c,}$ * \\ ${ }^{a}$ University of Bucharest, Faculty of Geography, Doctoral School 'Simion Mehedinți - Nature and Sustainable Development', Blvd. \\ Nicolae Bălcescu,1, 011041, Bucharest, Romania, e-mail: sofia_scaunas@yahoo.com \\ ${ }^{\mathrm{b}}$ University of Bucharest, Faculty of Geology and Geophysics, Geomatica Research Center, Traian Vuia 6, 020956, Bucharest, \\ E-mail: cornelpaun@gmail.com \\ c, * University of Bucharest, Faculty of Geology and Geophysics, Geomatica Research Center, Traian Vuia 6, 020956, Bucharest, \\ E-mail: george.merciu@geo.unibuc.ro
}

Received: 08.09.2019 / Accepted: 09.10.2019/ Revised: 02.11.2019 / Available online: 10.12.2019

DOI: 10.2478/jaes-2019-0026

KEY WORDS: urban history, post-socialist city, urban change, housing consumption, remote sensing, heat map.

\begin{abstract}
:
The paper topic is related to the use of Geographic Information System and remote sensing in analysing the spatio-temporal dynamics of a post-socialist city. The purpose of this study is to highlight the changes in the land use of the Băneasa neighbourhood, located in the northern part of the capital city of Romania. The changes have been analysed from the nineteenth century to the present. The authors used historical mapping using old maps, as well as digitizing aerial photographs using the Geographic Information System. There has been an accelerated territorial evolution in the last 70 years, marked by the impact of the socialist policy of intensive urbanization, when the urban-type systematization was applied through the construction of collective dwellings, to which were added some important industrial units. After 1990, the dynamics of the tertiary sector generated significant changes in the physiognomy of the urban landscape, observing the increase of the built space (commercial spaces, new residential areas) at the expense of green spaces, tree nurseries, greenhouses and industrial sites. The most recent stage of evolution, however, has brought the most profound changes in the landscape of the Băneasa district, as a result of the new political and socio-economic context, marked by the collapse of communism. Thus, in the last 30 years, the capital city has registered an uncontrolled urban growth dynamic, this being characteristic of other large urban centres at the national level as well favoured by less strict, inconsistent and incomplete urban legislation.
\end{abstract}

\section{INTRODUCTION}

Urbanization is considered a dominant factor of land use and land cover change that has determined population as well as economic activities' concentration in urban areas (Csachová, 2016; Kauko, 2019; Mbanga, 2018; Scăunaș, Merciu, 2016; Vlad Şandru et al., 2017), also contributing to the deterioration of the environmental quality at a local, regional and global scale. The accelerated pace of changes generates loss of green cover and other biodiversity elements, reducing fertile arable land (Bai et al., 2017; Dragoș et al., 2018; Grădinaru at al., 2015; Ianoș et al., 2017; Iojă et al., 2011; Peptenatu et al., 2016; Popescu et al., 2018), altering local and regional hydrology (Bai et al., 2017; Vlad Șandru et al., 2017), increasing the temperature and creating a heat island effect (Bai et al., 2017; Onačillová, Gallay, 2018; Scăunaș, Merciu, 2016; Sertel and
Akay, 2015; Sîrodoev et al., 2015) and air pollution (Bai et al., 2017; Peptenatu et al., 2016; Sertel, Akay, 2015).

In the context of urban population growth, the quality and quantity of green spaces are essential elements in urban management, they being an indicator of environmental quality (Colusca, Alpopi, 2011; Păcurar, 2017). Thus, the green areas are one of the most important functional areas within a city, contributing to the support of the quality of life in urban areas through the positive influence on the current climatic conditions, contributing the to purification of air and water, reducing the environmental pollution and so on (Adamczyk, Bieda, Parzych, 2019; Petrișor, 2015; Scăunaș, Merciu, 2016; Sîrodoev et al., 2015). Also important are the social valences of the green spaces as recreational areas, places for practising sports, as well as the aesthetic-environmental valences (Chiriac et al., 2009).

\footnotetext{
* Corresponding author. George-Laurentiu MERCIU, Researcher, e-mail: george.merciu@geo.unibuc.ro
} 
At the same time, land use and land cover change generate alteration of the cultural landscapes (Merciu et al., 2018; Petrişor, Petrişor, 2018) by eliminating landscape elements or even deteriorating them (Merciu et al., 2015; Schulp et al., 2019).

The collapse of the former political system in Central and Eastern Europe has led to major structural changes at the city level, and the economic element has undergone the most spectacular changes: a diversification of economic activities and attracting of foreign investments (Choromides, 2017; PichlerMilanović, 2005; Marcińczak et al., 2014), the tertiary sector has developed to the detriment of industrialization (Ianoș, 2004; Cercleux et al., 2015, Yaskal et al., 2018). In the early 1990s, for the central public administrations, territorial planning, regional development and housing policy did not represent priority areas (Pichler-Milanović, 2005). Consequently, territorial planning has been characterized by the prevalence of ad hoc political decisions and the laissez-faire approach, related to passive urban management (Ianos et al., 2017; PichlerMilanović, 2005). Thus, in this context, the political transition has changed the spatial characteristics of post-socialist cities, either as a result of urban expansion (Ianos et al., 2017; Kovács et al., 2019), or due to diversification of the economy (Cercleux et al., 2015; Choromides, 2017).

The purpose of this study is to analyse the evolution of land use in the northern part (Băneasa neighbourhood) of Bucharest (Figure 1), the capital of Romania, between 1864 and 2016.

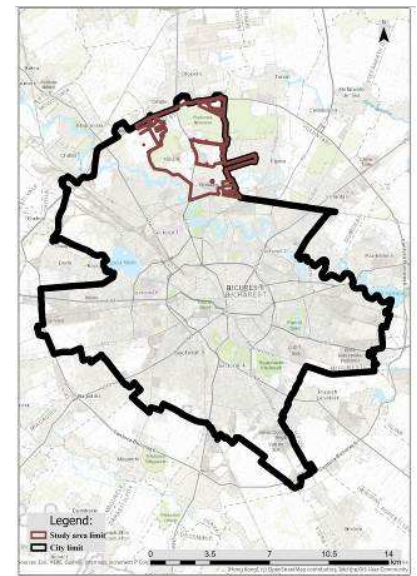

Figure 1. Location of the study area

The northern area of the capital city has experienced a dynamic economic in recent years, due to the development of the tertiary sector (commercial spaces, private medical services) becoming a prosperous area of the city.

\section{METHODOLOGY}

The Geographic Information System and remote sensing are used as methods for measuring and mapping models (Suba, Nistor, Suba, 2017) and trends of urban growth, and for monitoring the change of land use in the urban landscape (Drummond et al., 2019; Mbanga, 2018; Mihai et al., 2015; Popescu et al., 2018; Șandru et al., 2017; Scăunaș \& Merciu, 2016).
The use of old plans in mapping the long-term territorial evolution of urban centres has been used in numerous studies, such as on cities: Tehran (Taravat et al., 2017); Bucharest (Ianoș et al. 2017, Merciu et al., 2018, Munteanu, 2017); Belgrade (Orders, 2018); Gaziantep city (Sertel \& Akay, 2015).

To map the evolution of the Băneasa neighbourhood, old maps (Szathmári map, 1894, Bucharest city plans from 1910, 1930) and sketches made by Mihăilescu (2003) were used to extract information from the period when it was a commune. To capture the evolution of the neighbourhood since it was annexed to Bucharest and until now, the city plan of the communist period (1980) and aerial photographs from 2005 and 2016 were used. Both old plans and aerial photographs were imported into the GIS to be digitized in order to extract information on changing land use patterns.

In order to represent the density of built space in the study area a Heat Map was created through the dynamic method and Kernel Density Estimation. Heat map allows representation of geospatial data using different colors with different concentrations of points - showing overall shape and concentration trends (Netek, Pour, Slezakova, 2018, p. 368). Heat Map dynamic method is used to view the distribution of data in a particular area. Kernel Density Estimation has increasingly been used to examine the spatial distribution and frequency of land use (Scăunaș, Merciu, 2016; Bonnier et al., 2019; Merciu et al., 2018). Kernel Density Estimation is a useful method to investigate the density calculation and representation of spatially and temporally highly dynamic point data sets (Krisp, Peters, 2011).

\section{RESULTS AND DISCUSSIONS}

The history of the studied area begins 300 years ago, when it was known as the village Cârstienești, which was bought by the great ruler Mareș in the seventeenth century. 'Ban' meant 'great ruler', and the initial name of the village was changed after his wife's title, 'băneasa' (feminine of 'ban'/the title of the ban's, wife). At the end of the eighteenth century, a large part of the estate, already known as Băneasa, was bought by the great ruler Ştefan Văcărescu (Figure 2).

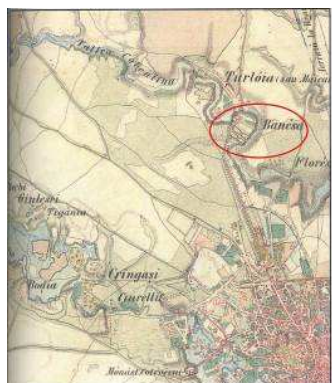

Figure 2. Representation of Băneasa commune on the Szathmári map (1864)

Băneasa commune experienced a parallel development with the evolution of Bucharest until the beginning of the twentieth century. The commune was part of the peri-urban area of the city. Due to the proximity to the capital city, there were mutual relations between the communes of the peri-urban area and the city. Thus, the first link between the polarizing city and the neighbouring communes was 
established on the basis of the supply of fresh fruits and vegetables to the population of the capital city. During the interwar period, the inhabitants of Băneasa commune were mainly dealing with the preparation of milk and cheese, which they brought to the city.

Also, besides its agricultural character, Băneasa commune also had the advantage of being an area of considerable tourist and recreational importance due to the presence of a large area of forest (624 ha) within its administrative boundaries. In the early $1900 \mathrm{~s}$, an aerodrome was built on the territory of Băneasa commune for short-distance flights. In 1912, Prince George Valentin Bibescu, the president of the Romanian Air League, set up a pilot school for military pilots in Băneasa.

Starting with the 1920s, with the application of the agrarian reform, which fragmented the land of the landlords, the intensification of relations between the polarizing city and the Băneasa commune can be observed. Thus, the homonymous airport, the first international airport in Romania, was built on the territory of Băneasa commune in 1920, by transforming the previously established aerodrome. In the same year, the Franco-Romanian Air Navigation Company, the first airline company in the world, for passengers, freight and mail was set up. In 1923, the airline's workshops were built on Băneasa Airport.

During this period the Meteorological Institute was built on the territory of Băneasa commune, in close relation to the activity of the airport. In 1930, the first Meteorological Observatory was built at Băneasa airport, which, among other things, also become a training centre.

In 1938, as a result of the growth of the economic potential of the Faculty of Agronomy within the Bucharest Polytechnic, was to have in operation six didactic farms, one of them being set up in the Băneasa commune (192 ha).

Băneasa commune is also important due to the hosting of military institutions, such as the Gendarmerie, whose headquarters were built in 1933 .

At the beginning of the twentieth century, the peripheral area of the capital city, of which all suburban communes belonged, was developing beyond the belt and barriers of Bucharest. This was very extensive, administratively delimited by a geometric polygon (Figure 3).

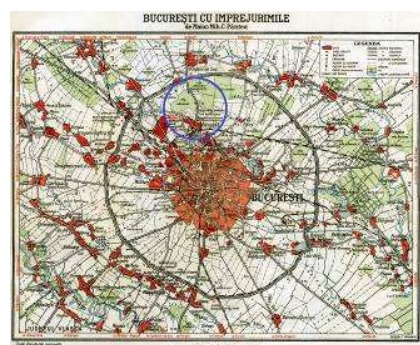

Figure 3. The plan of the city of Bucharest (1923) and its suburban area

From an administrative point of view, the peripheral area, of which the Băneasa commune also belonged, was not yet included in the city. The peripheral area still had a deeply agricultural character and the first industrial activities (based on the use of agricultural products) were beginning to take shape. Starting with this period, the communes around Bucharest had a suburban aspect, as a result of the increasing trend after 1920 of parcelling and transforming the territory due to the need to build working-class neighbourhoods, made up of cheap housing for craftsmen or minor officials (Mihăilescu, 2003) (Figure 3).

Starting with 1950, the peri-urban area of the capital city had undergone obvious and major changes from the urban point of view. But for the Băneasa commune, incorporated in the administrative boundaries of the city in 1950, the significant changes took place later compared to the other communes transformed into neighbourhoods in the northern part of the city (e.g. Floreasca, Herăstrău). Thus, the urban systematization in the Băneasa neighbourhood took place in the 1980s. The commune was transformed into the Băneasa neighbourhood. In the 1980s, the residential area was built, with a higher concentration in the southern part of the neighbourhood, at the border with the Floreasca and Herăstrău neighbourhoods (Figure 4). Also, the insertion of the residential area on the western and northern sides of the neighbourhood and north of Băneasa airport can be observed. The neighbourhood underwent a development of the industrial area, sometimes in alternation with the residential area. In Băneasa neighbourhood, however, the industrial area was smaller compared to other neighbourhoods that were also built during the communist period. Among the industrial units, we can mention: the radio and semi-conductor parts plant (IPRS Băneasa), the milling and bakery factory, Băneasa; the aircraft engine repair company (IRMA), the forerunner of the workshops of the FrenchRomanian Air Navigation Company, which was built between the $60 \mathrm{~s}$ and $70 \mathrm{~s}$. This company represented an aeronautical industrial complex that also owned an aircraft hangar.

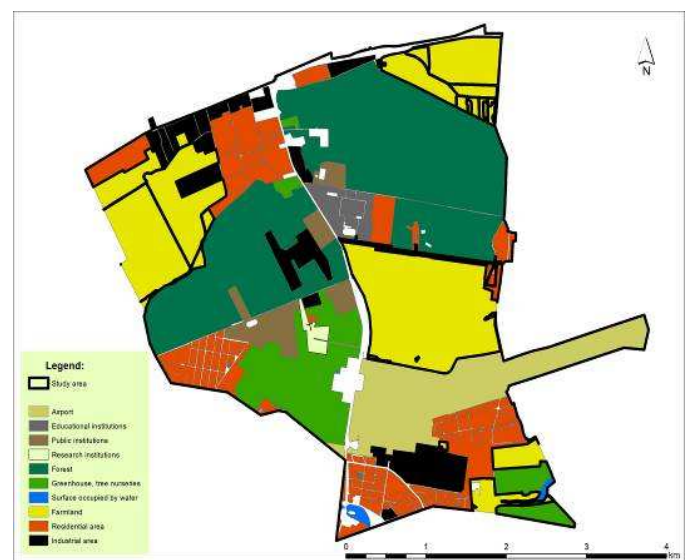

Figure 4. Map of land use in the Băneasa neighbourhood during the communist period (1980)

During the communist period, as a result of the development direction of the industry based on the exploitation of agricultural production, research centres were created that merged with higher education institutions: in 1948 the Bucharest Agronomic Institute was set up, which included in its composition the Faculties of Agriculture (formerly part of the Bucharest Polytechnic), Horticulture (established in 1948) and Mechanization of Agriculture (1948). In 1952, the Agronomic Institute merged with the Faculties of Zootechnics and Veterinary Medicine. After 1957, the didactic farms were integrated into the large farms of the state agricultural farms (Horticulture 1 May - greenhouses, Agricultural Production 
Cooperative Otopeni - acacia nursery, 81 ha). The Agronomic Institute was associated with the Băneasa experimental farm. The presence of the experimental areas of the faculties of agricultural and zootechnical profile justified the presence of a large area of agricultural land (208 ha), greenhouses and tree nurseries, sometimes being alternated with the residential area (Figure 4).

Also, in 1951, an urban plan was developed regarding the extension of the built space for agronomic faculties. The fields of the Faculty of Horticulture were organized in the Băneasa neighbourhood. In the new context, the 'Nicolae Bălcescu' Agronomic Institute underwent a series of transformations and modernizations of its structure, of the material basis. In addition, research institutes were created, focused on the mechanization of agriculture (in 1952 the Research Institute for the Mechanization and Electrification of Agriculture, the research enterprise for plant protection). Between 1957 and 1967, the first Institute for Horticultural Research in Romania was created, which represented the central production and research station for sericulture, occupying an area of 61 ha. In 1978, it was transformed into the Research-Development Station for fruit growing-Băneasa, Bucharest.

The period between 1990 and 2016 was marked by a dynamic growth of the built space, as a result of the changes made at the level of the capital city, generated mostly by the economic development dominated by the tertiary sector and the decline of industrial activity.

Two sub-stages can be distinguished, taking into account the amplitude of the changes in the use of the land (1990-2005 and 2006-2016). Thus, it is observed that between 1990 and 2005, the dynamics were slower, with little changes being observed during the communist period (Figure 5).

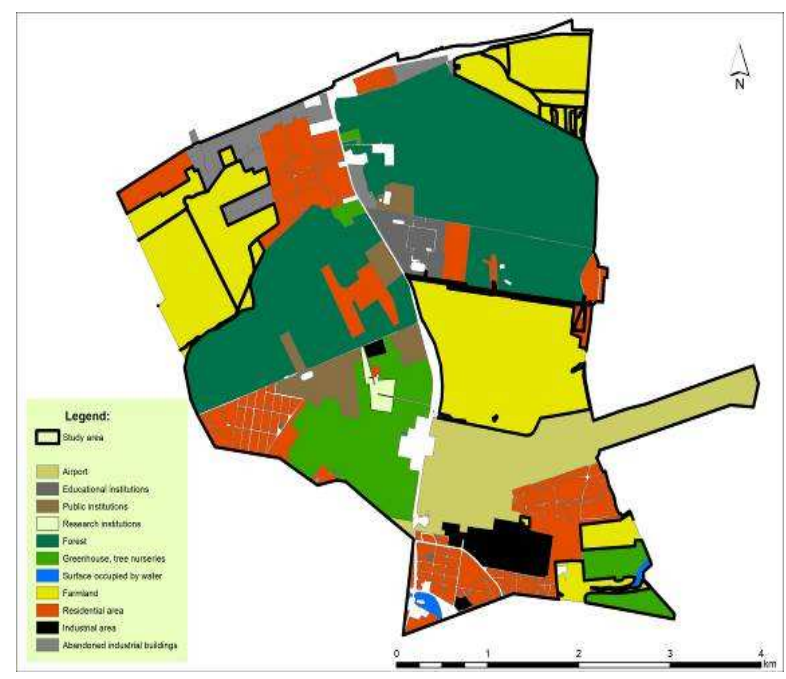

Figure 5. Map of the use land and use changes in Băneasa neighbourhood (2005) (Source: orthophotomap - National Agency for Cadastre and Real Estate Advertising)

Most of the changes consisted of reducing the industrial activity that led to the abandonment of some factories, and the increase of the built space due to projects of residential complexes that would be completed, for the most part, in the ensuing years.
Table 1. The evolution of land use in Băneasa neighbourhood from 2005 to 2016 (Source: data calculated by the authors)

\begin{tabular}{|c|c|c|}
\hline Types of surfaces & $\begin{array}{c}\text { Surface } \\
\text { (hectares) } \\
2005\end{array}$ & $\begin{array}{c}\text { Surface } \\
\text { (hectares) } \\
2016\end{array}$ \\
\hline $\begin{array}{c}\text { Constructions (civil } \\
\text { and industrial) }\end{array}$ & 106 & 134 \\
\hline $\begin{array}{c}\text { Green spaces } \\
\text { (including tree } \\
\text { nurseries) }\end{array}$ & 928 & 857 \\
\hline Forests & 650 & 640 \\
\hline Airport & 135 & 160 \\
\hline Land covered by water & 1 & 118 \\
\hline $\begin{array}{c}\text { Pavements and } \\
\text { arteries (streets) }\end{array}$ & 90 & $\mathbf{1 9 1 0}$ \\
\hline Total & $\mathbf{1 9 1 0}$ & \\
\hline
\end{tabular}

After 2006, significant changes can be observed in the urban landscape of Băneasa district due to the increase of the surface built space to the detriment of the green spaces or of the tree nurseries and orchards (Figure 6). The surface of the Băneasa orchard station decreased, so that at present it only owns half of the area held during the communist period ( $30 \mathrm{ha}$ ). The surface of the orchard station was divided following the retrocessions of land after 1990, so that later they were parcelled out and used differently. Part of the land was used to build offices for different firms (information technology: Siveco). On the same side commercial units for sale in the wholesale system have also been built (Selgros), hypermarkets (Mega Image), sports goods marketing store, car parks and car dealerships were built.

On another plot the commercial complex Băneasa Shopping Centre was built, opened in 2008. It is located in the central eastern part of the Băneasa neighbourhood.

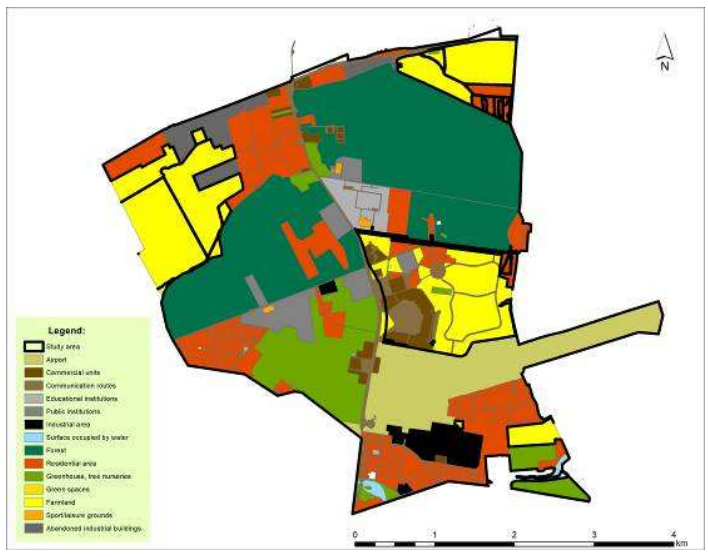

Figure 6. Map of land use and use changes in Băneasa neighbourhood (2016) (Source: orthophotomap - National

Agency for Cadastre and Real Estate Advertising)

The project for the development of the commercial complex included the Băneasa Shopping City mall, the Feeria Shopping Centre, as well as distinct units of some retailers in the field of commerce, furniture and home improvement (figure 7). The new commercial area covers an area of $450,000 \mathrm{~m}^{2}$. 


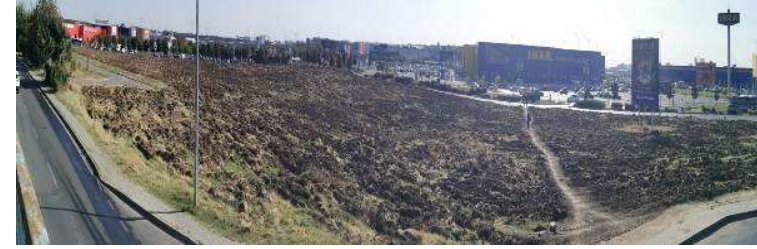

Figure 7. Commercial complex built on a plot of the Băneasa orchard station (photo: G. Merciu)

To these are added the headquarters of private TV companies, built all over the territory of the former orchard station.

Also, on the territory of Băneasa neighbourhood, after 1990 there was a remarkable development of private medical services, mostly as the result of foreign investments that had materialized through the construction of private clinics and hospitals.

In some cases, the extension of the built space was achieved by the demolition of some industrial units: e.g. the milling and bakery factory Băneasa (5 ha) demolished in 2014. A quarter of the former factory's surface was occupied by office buildings and hypermarkets.

Between 2006 and 2016, several residential complexes were built, some of them being built on the border with the Băneasa forest or even inside it. The 'Stejarii Club'/ 'Oaks Club' is a luxury residential complex that includes 19 blocks with 535 apartments. This residential complex was built in Băneasa forest and occupies an area of 26 ha, being built on the site that was occupied, during the communist period, by the Centre for the Professional Development of Agricultural Staff, and a farm.

At the periphery of Băneasa forest, several residential complexes were built: e.g. the Natura Residence comprising eight blocks with a height of three and five floors on a plot of 20,000 square meters. Another example is the Greenfield residential complex, located in the north-eastern extremity of Băneasa forest, built on the grounds of the former CAP Otopeni (acacia nursery). This residential area has been created in several stages, occupying an area of 27 ha (Figure 8).

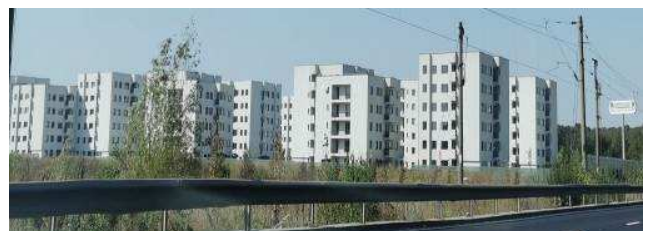

Figure 8. New residential area (Greenfield) built in the north-eastern part of the Băneasa neighbourhood (photo: Sofia Scăunaş)

Near the Băneasa Lake, Nordis Residence Băneasa Lake was built, which includes in its structure 6 buildings with $\mathrm{G}+2+3$ retired, occupying an area of 5,000 square meters.

Construction of new residential areas was also carried out in the central-eastern part of the neighbourhood, near the bus terminal and Băneasa airport, namely the Park Residence 6 complex, which occupies an area of 3 ha. Other changes in the landscape of the Băneasa neighbourhood are related to the construction of the French High School (2.4 hectare), in the north of the Băneasa area. Horticulture 1 May (greenhouses) had been in this area during the communist period.
The authors also represented the density of the built space in the Băneasa area by means of Heat Map (Figure 9).

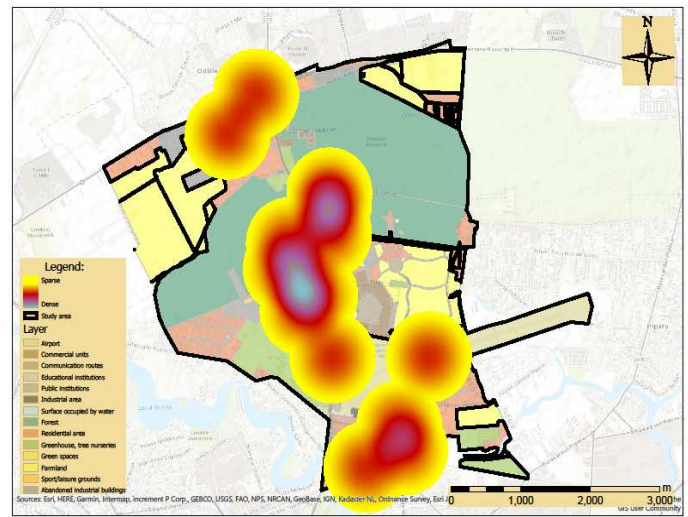

Figure 9. Heat Map for representing the built area density in Băneasa neighbourhood

The assessment of heat map produced as part of Kernel Density Estimation, highlights a greater concentration of built space in central and southern parts of the study area and an enclave in the northern part (Figure 9).

In southern area there are collective dwellings (70 blocks). The second nucleus in south area is made up predominantly of the buildings that serve the Băneasa Airport, as well as The Romanian Civil Aeronautically Authority, the Civil Aviation High School. The central nucleus is the largest and has the highest density of buildings in Băneasa area, including housing and comercial complexes, office buildings, embassies and institutions (Police Academy). In general, the lighter colors reflect a lower desnsity of the buildigns (houses interspersed with gardens). In the northen area, industrial buildings are predominant, în especially warehouses or abandoned buildings.

The analysis of the evolution of Băneasa commune over a period of 300 years emphasizes that during the last 70 years it has undergone the most visible changes, marked by the planned systematization of the communist period, followed by an uncontrolled urban development after the collapse of communism.

The creation of different institutions (research and military institutions) on the territory of the Băneasa commune, as well as the first international airport that served the country's capital, contributed to the welding of the links between the polarizing city and the suburban commune. To these are added the supply relations favoured on the one hand by the agricultural character of the commune, but also by its proximity to Bucharest. In this context, incorporating the Băneasa commune into the Bucharest municipality during the communist period represented a logical action of planned territorial systematization, especially since this way the connections already created were better structured, the new neighbourhood becoming a support space for agronomic higher education due to the resources it had (agricultural lands favourable to carrying out experiments and correlating agricultural production with the industrial valorisation). At the same time, the development of the city required the extension of the residential area, the former suburban commune having free spaces for the creation of new collective housing. 
The most recent stage of evolution, however, has brought the most profound changes in the landscape of the Băneasa district, as a result of the new political and socio-economic context, marked by the collapse of communism. Thus, in the last 30 years, the capital city, in the context of the transition from communism to a free market economy, has registered an uncontrolled urban growth dynamic, this being characteristic of other large urban centres at the national level as well (Ianoș et al., 2017) favoured by less strict, inconsistent and incomplete urban legislation.

Among the effects generated by the process of uncontrolled urban development we can mention: divergent tendencies between the provisions of the urban policies and the entrepreneurs, a real estate market that generated a fast and chaotic urban restructuring, also favoured by the restitution of the lands to the previous owners, who preferred to sell the lands because of their financial inability to manage them. In this context, the Băneasa neighbourhood, which had large areas of greenhouses and tree nurseries, represented an easier space to model according to the new economic trends (development of services, predominantly commercial ones) and residential requirements. The extension of the residential area in the northern part of the capital city after 1990 was made much earlier compared to the other areas of the city, especially as this is one of the most developed areas of Bucharest.

At the same time, the degree of development of the northern area of Bucharest municipality has attracted many investors who have developed different businesses in the field of information technology, private medical services and television. The construction of most investment projects has led to the reduction of agricultural areas and industrial sites.

\section{CONCLUSIONS}

The choice of the case study, the Băneasa neighbourhood, was due to its relatively long and staged evolution, strongly influenced by the evolution of the capital city. At the start of the second half of the nineteenth century, a city of Bucharest's size needed a planned development and resources from its adjacent space. The development of the transport infrastructure created the first link between Bucharest and the Băneasa commune, the latter ensuring the support space for the construction of the first international airport that served the capital city.

From a suburban commune during the interwar period, Băneasa became a Bucharest neighbourhood starting from the communist period, when the urban-type systematization was applied through the construction of collective dwellings, to which were added some important industrial units.

After 1990, the dynamics of the tertiary sector were reflected in the urban landscape through the construction of commercial complexes and offices. The development of services attracted an important segment of the young population in the capital city, which also led to the creation of new residential units.

\section{References:}

Adamczyk, T., Bieda, A., Parzych, P., 2019. Appraisal of real estate with various functions in the context of sustainable development. Journal of Applied Engineering Sciences, 9(22), 1, pp. 7-18. https://doi.org/10.2478/jaes-2019-0001.
Bai, X., McPhearson, T., Cleugh, H., Nagendra, H., Tong, X., Zhu, T., Zhu, Y-G., 2017. Linking urbanization and the environment: conceptual and empirical advances. Annual Review of Environment Resources, 42, pp. 215-240. https://doi.org/10.1146/annurev-environ-102016-061128.

Bonnier, A., Finné, M., Weiberg, E., 2019. Examining land use through GIS based Kernel Density Estimation: a re-evaluation of legacy data from the Berbati - Limnes Survey. J. of Field Archaeology, 40(2), pp. https://doi.org/10.1080/00934690.2019.1570481.

Cercleux, A.-L., Peptenatu, D., Merciu, F.-C., 2015. Structural dynamics of tertiary activities in industrial parks in Bucharest, Romania. Acta Geographica Slovenica, 55(2), pp. 271-281. doi:10.3986/ags.753.

Chiriac, D., Humă, C., Stanciu, M.. 2009. Spațiile verzi - o problemă a urbanizării actuale (Green space - a problem of current urbanization). Calitatea vieții, 20 (3-4), pp. 249-270.

Choromides, C., 2017. Analysis of the investment activity in South and Central Eastern Europe. A comparative analysis of the corporate growth model. J. of Urban and Regional Analysis, 10(1), pp. 5-32.

Colusca, S.E., Alpopi, C., 2011. The quality of Bucharest's green spaces. Theoretical and Empirical Researches. Urban Management, 6 (4), pp. 45-59.

Csachová, S., 2016. Inner boundary reform in Košice - the most fragmentated city in Slovakia. Geografica Pannonica, 20(3), pp. 152-160. doi: 10.5937/geopan1603152c.

Dragoș, M., Petrescu, A., Merciu, G.-L., Posner, C., 2018. The role of native ornamental plants in ensuring the habitat needs of birds in urban ecosystems. Case study - Cismigiu Garden, Bucharest. AgroLife Scientific Journal, 7(2), pp. 43-52.

Drummond, M. A., Stier, M., Diffendorfer, J. E., 2019. Historical land use and land cover for assessing the northen Colorado Front Range urban landscape. J. of Maps, 15(2), pp. 89-93. https://doi.org/10.1080/17445647.2018.1548383.

Grădinaru, S.R., Iojă, I.C., Onose, D.A., Gavrilidis, A.A., PătruStupariu, I., Kienast, F., Hersperger, A.M., 2015. Land abandonment as a precursor of built-up development at the sprawling periphery of former socialist cities. Ecological Indicators, $\quad 57, \quad$ pp. 305-313. https://doi.org/10.1016/j.ecolind.2015.05.009.

Kauko, T., 2019. How to pick relevant sustainability criteria for the built environment: a bottom-up approach. Urbanism Architecture Constructions, 10(1), pp. 11-22.

Ianoş, I., 2004. Dinamică urbană (Urban Dynamics). Tehnical Publishing House, Bucharest, pp. 25-26.

Ianoş, I., Sorensen, A., Merciu, C., 2017. Incoerence of urban planning policy in Bucharest. Its potential for land use conflict. Land Use Policy, 60, pp. 101-112. https://doi.org/10.1016/j.landusepol.2016.10.030. 
Iojă, C.I., Onose, D.A., Niță, M.R., Vânău, G.O., Pătroescu, M., Gavrilidis, A.A., Saghin, I., Zarea, R., 2011. The conversion of agricultural lands into built surfaces in Romania. Recent Res. Urban Sustain. Green Dev., 6, pp. 115-120.

Kovács, Z., Farkas, Z. J., Egedy, T., Kondor, A.C., Szabó, B., Lennert, J., Baka, D., Kohán, B., 2019. Urban sprawl and land conversion in post-socialist cities: the case of metropolitan Budapest. Cities, 92, pp. 71-81. https://doi.org/10.1016/j.cities.2019.03.018.

Krips, J. M., Peters, S., 2011. Directed kernel density estimation (DKDE) for time series visualisation. Annals of GIS, 17 (3), pp. 155-162.

Mbanga, L.A., 2018. Human settlement dynamics in the Bamenda III municipality, North West region, Cameroon. J. of Settlements and Spatial Planning, 9(1), pp. 47-58. Doi: 10.24193/JSSP.2018.1.05.

Marcińczak, S., Gentile, M., Rufat, S., Chelcea, L. 2014. Urban geographies of hesitant transition: tracing socioeconomic segregation in post-Ceausescu Bucharest. International J. of Urban and Regional Research, 38(4), pp. 1399-1417. https://doi.org/10.1111/1468-2427.12073.

Merciu, F.-C., Cercleux, A. L., Peptenatu, D., 2015. Roşia Montană, Romania: industrial heritage in situ, between preservation, controversy and cultural recognition. Industrial Archaeology Review, 37(1), pp. 5-19. https://doi.org/10.1179/0309072815Z.00000000039.

Merciu, C., Ianoș, I., Merciu, G.-L., Roy, J., Pomeroy, G., 2018. Mapping accessibility for earthquake response in the historic urban centre of Bucharest. Natural Hazards and Earth System Sci., 18, pp. 2011-2026. https://doi.org/10.5194/nhess-2017-13.

Merciu, C., Mavru, I., Iliescu, O. B., Merciu, G.-L. (2019). Delineation of the urban influence area using the multi-criteria assessment method. The case study of Focșani city, Romania, $J$. of Settlements and Spatial Planning, 10 (1), pp. 13-28. Doi: 24.193/JSSP.2019.1.02.

Mihai, B., Nistor, C., Simion, G., 2015. Post-socialist urban growth of Bucharest, Romania - a change detection analysis on landsat imagery (1984-2010). Acta geographica Slovenica, 55(2), pp. 223-234. Doi: 10.3986/ags.709.

Mihăilescu, V. (2003). Evolution of a city-Bucharest. Paideia Press, Bucharest, pp. 48-56.

Munteanu, A., 2017. Strada Sfintiii Apostoli - drumul ce ducea la vii. Reconstituirea unei vechi artere bucureștene (St. Apostoli' s street - the road leading to the vineyard. Reconstruction of the old Bucharest thoroughfare). Annals of the Profesional Association of Romanian Geographers, 8(8), pp. 53-62.

Netek, R., Pour, T., Slezakova, R., 2018. Implementation of Heat Maps in Geographical Information System - exploratory study on traffic accident data. Open Geosci., 10, pp. 367-384.

Pichler-Milanović, N., 2005. Urban development in Central and eastern Europe: from transition to «creative« competition?
In: Proceedings of the $41^{\text {st }}$ ISOCARP Congress, Bilbao, Spain, pp. 1-15, http://www.isocarp.net/Data/case_studies/585.pdf (view at 28 June 2019).

Peptenatu, D., Drăghici, C., Stoian, D., Pintilii, R.-D., Cercleux A.-L., Merciu, F.-C., Schvab, A., 2014. Qualitative changes in the entrepreneurial sector in emerging territorial systems Craiova case study. Acta Geographica Slovenica, 54 (2), pp. 293-310. Doi: 10.3986/ags54204.

Popescu, E.A., Kucsicsa, G., Bălteanu, D., Grigorescu, I., Mitrică, B., Dumitrașcu, M., Damian, N., 2018. Past and future land use/cover flows related to agricultural lands in Romania. An assessment using Clues model and Corine land Cover database. Carpathian Journal of Earth and Environmental Sciences, 13(2), pp. 613-628.

Petrișor, A.I., 2015. Assessment of green infrastructure of Bucharest using CORINE and Urban Atlas data. Urbanism, Architecture, Constructions, 6(2), pp. 19-24.

Petrișor, A. I., Petrișor, E., 2018. Transitional dynamics based trend analysis of land cover and use changes in Romania during 1990-2012. Present Environment Sustainable Development, 12(2), pp. 215-231. Doi: https://doi.org//10.2478/pesd-20180042 .

Orsini, H. F., 2018. Belgrade's urban transformation during the 19th century: a space syntax approach. Geografica Pannonica, 22(3), pp. 219-229. doi:10.5937/gp22-18026.

Onačillová, K., Gallay, M., 2018. Spatio-temporal analysis of surface urban heat island based on Landsat ETM+ and oli/tirs imagery in the city of Košice, Slovakia. Carpathian Journal of Earth and Environmental Sciences, 13(2), pp. 395-408.

Pătru-Stupariu, I., Stupariu, M., Cuculici, R., Huzui, A., 2011. Understanding landscape change using historical maps. Case study Sinaia, Romania. J. of Maps, 7(1), pp. 206-220. https://doi.org/10.4113/jom.2011.1151.

Scăunaș, S., Merciu, G., 2016. Using the LiDAR in analyzing the relationship between vegetation and built space - influences and interdependence. Case study: Bucharest Municipality. GeoPatterns, 2(1), pp. 6-12.

Sîrodoev, I., Cheval, S., Dumitrescu, A., Merciu, C., Văidianu, N., Paraschiv, A., Schvab, A., Saghin, A., Prefac, Z., 2015. Contribution of the built-up space to the creation of urban heat island in Bucharest Municipality. Journal of Environmental Protection and Ecology, 16 (4), pp. 1337-1343.

Schulp, C. J. E., Levers, C., Kuemmerle, T., Tieskens, K. F., Verburg, P. H., 2019. Mapping and modelling past and future land use change in Europe's cultural landscapes. Land Use Policy, 80, pp. 332-344. https://doi.org/10.1016/j.landusepol.2018.04.030.

Sertel, E., Akay, S.S., 2015. High resolution mapping of urban areas using SPOT-5 images and ancillary data. International $J$. of Environment and Geoinformatics, 2(2), pp. 63-76. https://doi.org/10.30897/ijegeo.303545. 
Suba, N. Sz., Nistor, S., Suba, Șt., 2017. Effects of DEM generating algorithms on water retention calculations in polders - a case study. J. of Applied Engineering Sciences, 7(20), 2, pp. 63-68. https://doi.org/10.1515/jaes-2017-0015.

Taravat, A., Rajaei, M., Emadodin, I., 2017. Urbanization dynamics pf Teheran city (1975-2015) using artificial neural networks. Journal of Maps, 13(1), pp. 24-30. https://doi.org/10.1080/17445647.2017.1305300.

Vlad Şandru M.-I., Iațu C., Șandru D. C., Cimbru, D. G., 2017. Approaching land-over-land use changes using statistical data validation for urban policies improvement. J. of Settlements and Spatial Planning, 8(2), pp. 119-129. doi: 10.24193/jpps.2017.2.05.

Yaskal, I., Maha, L.-G., Petrashchak, O., 2018. Spatial distribution of economic activities and internal economic integration in Romania. Journal of Urban and Regional Analysis, 10(2), pp. 217-239.

*** National Agency for Cadastre and Real Estate Advertising. 